DOI 10.18551/rjoas.2019-12.09

\title{
THE PRODUCTIVITY AND PROSPECTIVE OF COIX LACRYMA-JOBI L. FOR STAPLE FOOD CROP ALTERNATIVE IN EAST KALIMANTAN OF INDONESIA
}

\author{
Suyadi $^{1 *}$, Ince Raden ${ }^{2}$, Andi Suryadi ${ }^{1}$ \\ ${ }^{1}$ Department of Agrotechnology, Faculty of Agriculture, University of Mulawarman, Indonesia \\ ${ }^{2}$ Faculty of Agriculture, University of Kutai Kartanegara, Indonesia, \\ *E-mail: suyadi@faperta.unmul.ac.id
}

\begin{abstract}
Coix lacryma-jobi L. (Job's tears) are a native food crop biodiversity of East Kalimantan, this crop generally cultivated altogether with upland rice under sifting cultivation practice. However, since the implementation of rice intensification program by Indonesian government, Job's tears was left and neglected by farmers along with the reduction of upland rice cultivation practice. The prospective of Job's tears development as a staple food crop in East Kalimantan was determined by its biological characteristics as a C4 and adapted to the upland ecosystem. This is an initial study of long term research plan for Job's tears development in East Kalimantan, to evaluate some experiments on productivity of Job's tears under traditional cultivation and fertilizer application. The productivity of Job's tears was determined by using some indicators, i.e. crop yield, number of tillers, number of grain per panicle, and grain weight. Results of the study showed that the average productivity of Job's tears under traditional cultivation was about 5 metric ton ha ${ }^{-1}$ and varies from about 3 metric ton up to $>8$ metric ton ha ${ }^{-1}$. Application of compound fertilizer at the dosage of $200 \mathrm{~kg} \mathrm{ha}^{-1}$ was increased the 1.000 grain weight more than $15 \%$ and also increased grain yield more than $25 \%$. Those data elaborated that Job's tears productivity might be improved through soil fertility management, and it was prospective to develop as staple food crop alternative for staple food diversification program in East Kalimantan.
\end{abstract}

\section{KEY WORDS}

Job's tears, productivity, staple food, diversification, East Kalimantan.

Currently food diversification in Indonesia continues to be carried out in order to change and improve people's consumption patterns, so that more diverse types of food with better nutritional quality (Singha, Choudhary, \& Vishnu, 2014). Food diversification will make people get a variety of carbohydrate sources and types of plants other than rice. One of the efforts to diversify food in Indonesia is to utilize the potential of diversification of local crop commodities in the production, consumption and distribution subsystems at both the regional and national farm level towards achieving structural transformation of the agricultural sector towards resilient agriculture (Wahyuningsih, 2008).

The efforts to increase staple food crop production is the main world issue, deficit in food crop production was occurred in many countries, especially in developing countries (FSIN 2017). The climate change and the availability of suitable soil for crop production were considered as the main limiting factors, aside the shortage in some requirement resources for crop production (FAO 2016) (Ruminta, Nurmala, and Wicaksono 2017). The provincial government policy on food security should be reformatted, from the rice-based staple food sifted into diversity staple food crops. There was some potential staple food crops alternative available in East Kalimantan, e.g., cassava, corn, sweet potato, sago, job's tears, and so on. The production development for those alternative food crops was prospective, especially for those crops which adaptive to the upland environmental condition (Badan Pusat Statistik 2013).

The alternative staple food candidate must be accomplishing some requirements which adapted to socio-cultural of people locally. While nutrient content of the alternative food crop was another consideration, it must be as good as nutrient content of rice or better (Bhandari et al. 2012; Nurmala 2011). The alternative staple food might be accepted by people as well 
as they taste and consumed rice for daily foods (Kennedy et al. 2017). Based on the some consideration criteria stated above, Job's tears is one the best food crop alternative candidate. Job's tears could be used as the component of staple food diversity program in combination with rice, which is eaten in the same way as rice, alone or mixed with it. It can substitute rice in all foodstuffs (Hore and Rathi 2007; van den Bergh and lamsupasit, 1996.

Job's tears ("lore" dayak language) actually is a local natural biodiversity of East Kalimantan Province (http://kaltim.litbang.pertanian.go.id); this crop was usually planted together with upland rice in shifting cultivation system. However, since the intensification rice production program which focused on lowland rice was implemented by the Government of Indonesia, Job's tears become left and neglected by farmer. In fact, Job's tears have some superior characters compared to other alternative food crops and rice, e.g. (1) in sociocultural aspects, (2) cultivation aspects, and (3) nutritional content aspects. In socio-cultural aspects: (a) native East Kalimantan farmer already familiar with this crop, (b) it could be prepared and cooked as rice, (c) its taste not so different with rice - there were also sticky and non-sticky Job's tears varieties. In cultivation aspects: (a) Job's tears adapted to upland environmental condition, (b) high capacity to compete for weeds, (c) adaptive to global warming as the impact of climate change, and (d) more productive compared to upland rice (Burnette 2012). In nutritional content aspects: (a) Job's tears has nutrition content better than rice, especially for protein content (Chhabra and Gupta 2015), (b) beneficial as functional food which effective to prevent and cure some human sickness (Chaisiricharoenkul et al. 2011) - such as cancer (Xi et al. 2016; Qu et al. 2013), diabetes ( $\mathrm{Ha}$ do et al. 2010; Li et al. 2004), and others (Ragasa et al. 2014; Hayashi et al. 2009; Chhabra and Gupta 2015).

Based on the background as elaborate above, the experimental purposes were to evaluate the prospect of Job's tears as the alternative staple food crop and to promote the staple food crops diversity program in East Kalimantan. In order to settle the shorted problem of lowland rice availability and to useful the upland availability for cultivation of adapted food crop. So, self-sufficient in staple food crops production in the province could be realized, and hopefully the health quality index of East Kalimantan people will be getting higher and higher due to consuming the Job's tears which was distributed evenly in the province.

\section{METHODS OF RESEARCH}

The field experiment was carried out at Loa-Kulu Sub-district, Kutai Kartanegara District, East Kalimantan Province as the center for Job's tears pilot project development in the province. The experimental site is about $20 \mathrm{Km}$ away from Tenggarong City, the capital of Kutai Kartanegara District. The environmental characteristic of the experimental site could be elaborated as the following: (1) weather condition was affected by the tropical rain forest climate: average temperature $28,70^{\circ} \mathrm{C}$ (maximum $36,20^{\circ} \mathrm{C}$ and minimum $22,20^{\circ} \mathrm{C}$ ), average humidity $82 \%$ (maximum $100 \%$ and minimum $40 \%$ ), precipitation $2,097.80 \mathrm{~mm}^{3}$, sunshine duration 46.80\% (Badan Pusat Statistik 2016); (2) soil properties: the experiment of fertilizer treatments was conducted at rain-field lowland area, this area during rainy season might experience flooded for some times, while the experiment of productivity evaluation was conducted at upland area.

This experiment was composed of two field experiments; the first section was focused on the evaluation of Job's tears response to fertilizer treatments under a plot experimental design. The second section was focused on the evaluation of Job's tears productivity under traditional cultivation system which commonly applied by farmer.

The fertilizer experiment was arranged in a randomize block design with four fertilizer treatments, and three replications were applied for each treatment. Fertilizer used in the experiment was the NPK $(15-15-15)$ fertilizer and the cow dung. Those four fertilizer treatments were implemented as the following: (i) $F_{0}=$ without fertilizer application as check treatment; (ii) $F_{1}=$ NPK fertilizer, 20 gr per plant was applied at 30 days after sowing (DAS) $200 \mathrm{~kg} \mathrm{ha}^{-1}$; (iii) $\mathrm{F}_{2}=\mathrm{NPK}$ fertilizer, $20 \mathrm{gr}$ per plant was applied at 30 and 70 DAS $\sim 400 \mathrm{~kg}$ 
ha $^{-1}$; (iv) $F_{3}=$ NPK fertilizer, 20 gr per plant was applied at 30 and 70 DAS, + application of dung.

After a week of cow dung application at the dosage of about 5 metric ton ha ${ }^{-1}$ for the all treatments, then the Job's tears seed were sowed at three seed per hole with the planting space of about $80 \times 100 \mathrm{~cm}$.

The experiment was carried out followed the traditional cultivation system applied by the upland rice farmer, to determine the attainable yield or productivity of Job's tears. Zerotillage land preparation was conducted through slash and burn practice. Then cow dung fertilizer at the dosage of about 5 metric ton ha $^{-1}$ was applied evenly all over the area. One week after cow dung application, Job's tears seed were sowed at three seed per hole with the planting spacing of about $80 \times 100 \mathrm{~cm}$.

The purposive sampling was implemented to measure the Job's tears productivity within two-hectare area, based on the plant growth performance of Job's tears which was grouped into four criteria : (1) crop clump with 5 members, (2) crop clump with 15 members, (3) crop clump with 25 members, and (4) crop clump with $>35$ members, representing crop productivity from the lowest up to the highest.

The analysis of variance was implemented to analyze the data of fertilizer treatment experiment, and then followed by least significant difference test. The descriptive analysis was carried out for Job's tears productivity evaluation, to describe the data of yield components and to estimate the attainable yield of Job's tears.

\section{RESULTS AND DISCUSSION}

The productivity of Job's tears was determined based on the two sections of field experiment; the first one was focus on the fertilizer treatments, while the second experiment was focus on attainable yield under traditional cultivation system. The environmental factor that likely affects productivity on Job's tears at each experimental field was flooded incident which occurred at the fertilizer experiment field. Heavy rain for about two months at the end of experiment was caused seed shed significantly and reduced harvested seed of Job's tears. That way, the productivity of Job's tears at experimental site Section 1 was considered lower than the productivity at experimental site Section 2.

The increasing of fertilizer dosage significantly increased grain yield of Job's tears (Table 1$)$. The highest grain yield ( $246.88 \mathrm{~g}$ per clump) was reached by $\mathrm{P}_{3}$ treatment as the highest dosage of fertilizer application, followed by $\mathrm{P}_{2}$ treatment which received the same dosage of inorganic fertilizer as in the $P_{3}$ treatment, but without cow dung organic fertilizer. While, $P_{1}$ as the lowest dosage of fertilizer treatment produced the lowest grain, but still significantly different with $\mathrm{P}_{0}$ as the check without fertilizer application.

Table 1 - The effect of fertilizer treatment on the average dry weight of Job's tears seed

\begin{tabular}{cccc}
\hline \multirow{2}{*}{ Treatment } & \multicolumn{3}{c}{ Dry weight $(\mathrm{g})$ seed } \\
\cline { 2 - 4 } & 1000 seed & Seed per panicle & Seed per clump \\
\hline $\mathrm{P}_{0}$ & 94.24 & $11.78^{\mathrm{a}}$ & $168.75^{\mathrm{a}}$ \\
$\mathrm{P}_{1}$ & 109.20 & $13.95^{\mathrm{b}}$ & $212.50^{\mathrm{b}}$ \\
$\mathrm{P}_{2}$ & 115.45 & $15.42^{\mathrm{c}}$ & $239.58^{\mathrm{c}}$ \\
$\mathrm{P}_{3}$ & 121.40 & $17.29^{\mathrm{a}}$ & $246.88^{\mathrm{a}}$ \\
\hline
\end{tabular}

Note: Values at the same column followed by the same letter are not significantly different at $L S D(P=5 \%)$.

The effect of fertilizer treatments on grain yield of Job's tears was likely supported by the grain weight. The increase of fertilizer dosage application tends to increase the average of 1,000 seed weight and significantly increased the average of seed weight per panicle. While, number of seed per panicle (Table 2) and number of tiller per clump (Table 3) were not significantly different for all of fertilizer treatment, except for the number of total seed for $\mathrm{P}_{3}$ treatment (Table 2).

The number of non-productive tiller was an important data in determining productivity of Job's tears. The percentage of non-productive in this experiment was relatively height 
(>45\%), and no significant different between fertilizer application and without fertilizer application (Table 3).

Table 2 - The effect of fertilizer treatment on the average number of Job's tears seed per panicle

\begin{tabular}{cccc}
\hline \multirow{2}{*}{ Treatment } & \multicolumn{3}{c}{ Number of seed per panicle } \\
\cline { 2 - 4 } & Total seed & Empty seed & \% empty seed \\
\hline $\mathrm{P}_{0}$ & $125.00^{\mathrm{a}}$ & $9.50^{\mathrm{a}}$ & 7.6 \\
$\mathrm{P}_{1}$ & $127.75^{\mathrm{a}}$ & $14.08^{\mathrm{a}}$ & 11.0 \\
$\mathrm{P}_{2}$ & $133.57^{\mathrm{a}}$ & $11.78^{\mathrm{a}}$ & 8.8 \\
$\mathrm{P}_{3}$ & $142.42^{\mathrm{b}}$ & $10.88^{\mathrm{a}}$ & 7.6 \\
\hline
\end{tabular}

Note: Values followed by the same letter in the same column are not significantly different at $L S D(P=5 \%)$.

Table 3 - The effect of fertilizer treatment on the average number of Job's tears tiller at 117 DAS

\begin{tabular}{cccc}
\hline \multirow{2}{*}{ Treatment } & \multicolumn{3}{c}{ Number of tiller per clump } \\
\cline { 2 - 4 } & Total tiller & Non-productive tiller & \% Non-productive tiller \\
\hline $\mathrm{P}_{0}$ & $45.77^{\mathrm{a}}$ & $21.69^{\mathrm{a}}$ & 47.39 \\
$\mathrm{P}_{1}$ & $49.64^{\mathrm{a}}$ & $22.44^{\mathrm{a}}$ & 45.21 \\
$\mathrm{P}_{2}$ & $48.28^{\mathrm{a}}$ & $22.77^{\mathrm{a}}$ & 47.16 \\
$\mathrm{P}_{3}$ & $49.79^{\mathrm{a}}$ & $23.36^{\mathrm{a}}$ & 46.92 \\
\hline
\end{tabular}

Note: Values at the same column followed by the same letter are not significantly different at $L S D(P=5 \%)$.

The response of Job's tears to the fertilizer treatment was also showed by plant height variable, all fertilizer treatments resulted in the higher plant height than that of without fertilizer treatment at 60 DAS. However, plant height of Job's tears at early state of plant growth was not showed any differences (Table 4).

Table 4 - The effect of fertilizer treatment on the average plant height of Job's tears

\begin{tabular}{cccccc}
\hline \multirow{2}{*}{ Treatment } & \multicolumn{5}{c}{ Plant height $(\mathrm{cm})$} \\
\cline { 2 - 6 } & 15 DAS & 30 DAS & 45 DAS & 60 DAS & 75 DAS \\
\hline$P_{0}$ & $21.69^{\mathrm{a}}$ & $45.77^{\mathrm{a}}$ & $94.08^{\mathrm{a}}$ & $114.46^{\mathrm{a}}$ & $198.69^{\mathrm{a}}$ \\
$\mathrm{P}_{1}$ & $22.44^{\mathrm{a}}$ & $49.64^{\mathrm{a}}$ & $98.15^{\mathrm{a}}$ & $132.15^{\mathrm{b}}$ & $234.49^{\mathrm{b}}$ \\
$\mathrm{P}_{2}$ & $22.77^{\mathrm{a}}$ & $48.28^{\mathrm{a}}$ & $97.10^{\mathrm{a}}$ & $132.69^{\mathrm{b}}$ & $232.05^{\mathrm{b}}$ \\
$\mathrm{P}_{3}$ & $23.36^{\mathrm{a}}$ & $49.79^{\mathrm{a}}$ & $102.18^{\mathrm{a}}$ & $130.08^{\mathrm{b}}$ & $220.00^{\mathrm{b}}$ \\
\hline
\end{tabular}

Note: Values followed by the same letter in the same column are not significantly different at $L S D(P=5 \%)$.

All of vegetative and generative data listed above (Table 1, 2, 3, and 4), approved that Job's tears response to the fertilizer application. The important variable for determining the response of Job's tears to fertilizer treatments were (1) grain yield, (2) seed weight per panicle, (3) weight of 1,000 seed, and (4) plant height.

The experimental field for the Job's tears productivity evaluation at the traditional cultivation system was conducted at upland farmer field, topography of the area was undulating and soil fertility status was not evenly distributed at all over the field. However, plant growth performance was varied depend on the soil fertility status where they established. Furthermore, plant samples were arranged through a purposive sampling procedure within area of about two hectares, Job's tears field was differentiated into four groups based on the plant growth performances, i.e. (1) crop clump with 5 members, (2) crop clump with 15 members, (3) crop clump with 25 members, and (4) crop clump with >35 members. The yield component data of Job's tears elaborated interesting information. There is a negative model of correlation between number of Job's tears clump member with the number of seed per panicle and seed dry weight per panicle of Job's tears (Table 5). The less number of Job's tears clump member, the more number of seed per panicle, and vice versa. A negative correlation between the numbers of Job's tears clump member with the seed dry weight per panicle was also observed. However, the numbers of Job's tears clump member positively correlated with the weight of 1,000 seed. The data informed that seed weight of Job's tears was affect by soil fertility, the good performed of Job's tears growth must be established on the fertile soil. 
Table 5 - The average yield component of Job's tears under traditional cultivation system

\begin{tabular}{ccccc}
\hline \multirow{2}{*}{$\begin{array}{c}\text { Member of Clump } \\
\text { (Tiller) }\end{array}$} & \multicolumn{4}{c}{ Yield component } \\
\cline { 2 - 5 } & $\begin{array}{c}\text { Number of Seed per } \\
\text { Panicle }\end{array}$ & $\begin{array}{c}\text { \% of Empty Seed per } \\
\text { Clump }\end{array}$ & $\begin{array}{c}\text { Seed Weight per } \\
\text { Panicle }(\mathrm{g})\end{array}$ & $\begin{array}{c}\text { Weight of 1,000 } \\
\text { Seed }(\mathrm{g})\end{array}$ \\
\hline 5 & 609 & 3.27 & 43.95 & 72.21 \\
15 & 349 & 9.00 & 25.71 & 73.58 \\
25 & 345 & 6.99 & 24.87 & 78.28 \\
$>35$ & 225 & 4.55 & 17.03 & 81.62 \\
\hline
\end{tabular}

The number empty seed was the only one independent variable of Job's tears yield component, this variable was not affected by the number of Job's tears clump member as well as number of seed per panicle. However, the number of empty seed tended to reduce by the increasing of soil fertility (Table 5), and the balance nutrient availability was expected to play an important role in reducing number of Job's tears empty seed.

Table 6 - The estimation of Job's tears attainable yield under traditional cultivation system

\begin{tabular}{|c|c|c|c|c|c|}
\hline \multirow[b]{2}{*}{$\begin{array}{c}\text { Member of Clump } \\
\text { (Tiller) }\end{array}$} & \multicolumn{5}{|c|}{ Attainable yield } \\
\hline & $\begin{array}{c}\text { Number of Seed } \\
\text { per Clump }\end{array}$ & $\begin{array}{c}\text { Number of Empty Seed } \\
\text { per Clump }\end{array}$ & $\begin{array}{l}\text { Seed Weight per } \\
\text { Clump } \\
(\mathrm{g})\end{array}$ & $\begin{array}{l}\text { Weight of } \\
1,000 \\
\text { Seed } \\
(\mathrm{g})\end{array}$ & $\begin{array}{l}\text { Attainable Grain Yield } \\
\text { (ton ha }{ }^{-1} \text { ) }\end{array}$ \\
\hline 5 & 3043 & 103 & 219.75 & 72.21 & 2.75 \\
\hline 15 & 5242 & 472 & 385.71 & 73.58 & 4.82 \\
\hline 25 & 7941 & 555 & 621.64 & 78.28 & 7.77 \\
\hline$>35$ & 8344 & 398 & 681.05 & 81.62 & 8.51 \\
\hline
\end{tabular}

The attainable yield of Job's tears through the traditional cultivation system conducted by farmer was an appropriate measure to estimate the productivity of Job's tears in East Kalimantan. The yield components were good indicator to estimate the productivity of Job's tears in the field. Soil fertility levels which recognized by plant growth performance as settled in the sampling plan was consistently elaborated the attainable yield of Job's tears in the field. Based on the soil fertility level differences all over the experimental field, the Job's tears productivity was varied from 2.75 up to 8.51 metric ton ha $^{-1}$ under traditional ciltivation system. However, due to the lower productivity plant proportion was dominated, so the estimate productivity was settling at 5.00 metric ton ha ${ }^{-1}$.

The productivity of Job's tears, affected by fertilizer application (Table 1). The same results were also reported by (Jampeetong et al. 2013) and (Juhaeti 2015) that fertilizer increased the growth and yield Job's tears. Furthermore, the attainable yield of Job's tears under traditional cultivation system, varies from 2.75 to 8.51 metric ton ha ${ }^{-1}$ due to the differences in soil fertility status in the field (Table 6). The attainable yields in this experiment were considered in a range or higher than the Job's tears productivity reported by (Nurmala 2011) and (Burnette 2012).

The important information in this experiment is that the productivity of Job's tears in the experimental site Section 2 was higher than in the experimental site Section 1, due to the flood incident in the experimental site Section 1. The experimental site Section 1 was situated in a plate area and flood in hard rainy season. The average of total seed per panicle in the experimental site Section 1 (Table 2), was just a half of that in the Section 2 (Table 5), in the same criteria plant (having $>35$ tillers per clump). Furthermore, the number of nonproductive tiller the Section 1 was considered high; it was more than $45 \%$ for all of the treatment. It was due to imbalance nutrient uptake by the crop as the impact of flooded and fertilizer application.

Based on the attainable grain yield of Job's tears under traditional cultivation system (Table 6) and response of Job's tears to the fertilizer treatment (Table 1), it was concluded that Job's tears is prospective to be developed an alternative of staple food crop in East Kalimantan. The attainable yield of Job's tears was higher than that of upland rice productivity, the average productivity of upland rice in East Kalimantan just about 2.61 metric ton ha ${ }^{-1}$ (Badan Pusat Statistik 2016). While, the low productivity of Job's tears could be 
improved through fertilizer treatment and other cultivation management (Jampeetong et al. 2013; Juhaeti 2015; (Ruminta, Nurmala, and Wicaksono 2017).

There are some consideration factors that support the prospective of Job's tears development in East Kalimantan, i.e. (1) to realize food security in the province based on the local resources, (2) the upland area availability, (3) the adaptability of Job's tears as C4 crop to the climate change and global warming (FAO 2016). As state above, one of the limiting factor to realize self-sufficient rice production in the province is the inadequate of lowland rice field availability. Whereas, upland area more available in all district of East Kalimantan Province (Badan Pusat Statistik 2013).

Response to climate change, Job's tears as C4 crop (Protabase 2009) more adaptive to climate change compared to rice as $\mathrm{C} 3 \mathrm{crop}$, especially related to the global warming as the impact factor of climate change. The optimum temperature ambient of rice (C3 crop) photosynthesis was determined $<30^{\circ} \mathrm{C}$, while Job's tears as the C4 crop their photosynthesis activities and processes still running well at the temperature $\geq 35^{\circ} \mathrm{C}$ (Sage and Kubien 2007; Yamori, Hikosaka, and Way 2014). In fact, the average temperature in experimental site and East Kalimantan in general was about $28,70^{\circ} \mathrm{C}$ (maximum $36,20^{\circ} \mathrm{C}$ and minimum $22,20^{\circ} \mathrm{C}$ ) (Badan Pusat Statistik 2016), and in the day time when the photosynthetic processes were occurred, temperature at above of crop canopy tend more than $30^{\circ} \mathrm{C}$. Therefore, very difficult to increase the rice productivity in East Kalimantan within last five years. Whereas, the productivity Job's tears as the C4 crop will be supported by that temperature ranges and further increase up to $40^{\circ} \mathrm{C}$ (Yamori, Hikosaka, and Way 2014). Moreover, Job's tears has another superior characters compared to the upland rice, especially in term of the capacity for competition to weeds and soil fertility conservation (Burnette 2012); van den Bergh and lamsupasit, 1996).

The availability of lowland rice field, as the main area of rice production in East Kalimantan was still far from the minimum standard for rice production to realize selfsufficient in the province with more than 3.5 million populations. To perform the self-sufficient of rice production in East Kalimantan required about 150,000 hectare of lowland rice field, but the availability of lowland rice field in the province still $<70,000$ hectare (Badan Pusat Statistik 2016). However, the availability of upland area allocated for agriculture production still high, and it is prospective for the Job's tears area production as the crop which adapted to the upland environment (Badan Pusat Statistik 2013, 2016). Likewise, under proper crop management practices, Job's tears could be cultivated at the marginal soil (Nurmala, 2011), it was opened more chance to cultivate this crop at any bare soil around villages in the province.

The self-sufficient rice production, which is still difficult to realize in East Kalimantan could be solved through staple food diversification program, by introducing Job's tears as the alternative food crop. Beside the prospective of Job's tears development based on the response to climate change and upland area availability as elaborated above, Job's tears seed has nutrition value better than rice, especially in protein content (Shiva Ram Bhandari et al. 2012; Nurmala 2011). So, Job's tears was fulfilling some requirements to become a good candidate for alternative staple food crop, and it could be implemented in staple food diversification program altogether with rice (Brink and Belay, 2006).

Other than all prospective characters state above, the development of Job's tears production will contribute a beneficial impacts on people healthiness due to Job's tears role as functional food (van den Bergh and lamsupasit 1996; Shiva Ram Bhandari et al. 2012; Lugli et al. 2002; Lakkham, Wangsomnuk, and Aromdee 2009). There are many finding that determine Job's tears role in the prevent and cure some human sickness, e.g. (1) reproductive and digastric system cancer (Qu et al. 2013) (Chaisiricharoenkul, Tongta, and Intarapichet 2011; Shiva Ram Bhandari et al. 2012; Chhabra and Gupta 2015; Hsia et al. 2007), (2) diabetic (Li et al. 2004), (3) obesity (Ragasa et al. 2014), and more others. 


\section{CONCLUSION}

The increasing of fertilizer dosage significantly increased grain yield of Job's tears, The highest grain yield ( $246.88 \mathrm{~g}$ per clump) was reached by $\mathrm{P}_{3}$ treatment as the highest dosage of fertilizer application, and $P_{1}$ as the lowest dosage of fertilizer treatment produced the lowest grain, but still significantly different with $\mathrm{P}_{0}$ as the check without fertilizer application. The productivity of Job's tears was determined by using some indicators, i.e. crop yield, number of tillers, number of grain per panicle, and grain weight. The average productivity of Job's tears under traditional cultivation was about 5 metric ton ha ${ }^{-1}$ and varies from about 3 metric ton up to $>8$ metric ton ha ${ }^{-1}$. Application of compound fertilizer at the dosage of $200 \mathrm{~kg}$ ha $^{-1}$ was increased the 1.000 grain weight more than $15 \%$ and also increased grain yield more than $25 \%$. Those data shows that Job's tears productivity might be improved through soil fertility management.

\section{REFERENCES}

1. Badan Pusat Statistik. 2013. Sensus Pertanian 2013 Kalimantan Timur. Samarinda: BPS Provinsi Kalimantan Timur. https://kaltim.bps.go.id.

2. Badan Pusat Statistik. 2016. Kalimantan Timur in Figures 2016. Samarinda: BPS Provinsi Kalimantan Timur. https://kaltim.bps.go.id.

3. Brink M and Belay G. 2006. Plants Resources of Tropical Africa 1: Cereals and pulses. PROTA Faoundation, Wageningen.

4. Burnette R. 2012. Three cheers for Job's tears: Asia's other indigenous grain." ECHO Asia Impact Center, No. 13: 13-17.

5. Chaisiricharoenkul J, Tongta S, and Intarapichet K. 2011. Structure and chemical and physicochemical properties of Job's tear (Coix lacryma-jobi L.) kernels and flours. Suranaree J.Sci. Technol. 18 (2): 109-22.

6. Chhabra D and Gupta RK. 2015. Formulation and phytochemical evaluation of nutritional product containing Job's tears (Coix lachryma-jobi L.). Journal of Pharmacognosy and Phytochemistry 4 (3): 291-98.

7. FAO. 2016. The state of food and agriculture: climate change, agriculture and food security. Rome. http://www.fao.org/3/a-i6030e.pdf.

8. FSIN. 2017. "Global Report on Food Crises 2017," 145. http://documents.wfp.org/stellent/groups/public/documents/ena/wfp291271.pdf?_ga=2.75 146514.1285312314.1495809857-1703997290.1495809065.

9. Ha do T, Nam Trung T, Bich Thu N, Van On T, Hai Nam N, Van Men C, Thi Phuong T, and Bae K. 2010. Adlay seed extract (Coix lachryma-jobi L.) decreased adipocyte differentiation and increased glucose uptake in 3T3-L1 Cells. J Med Food 13 (6): 133139. doi:10.1089/jmf.2010.1155.

10. Hayashi H, Ohta Y, Arai T, Shimano Y, Takano F, Strong JM, Enomoto T, Uebaba K, Ohta T, and Suzuki N. 2009. Acute oral toxicity test of hot water extract of Coix lacrymajobi L. var. ma-yuen Stapf in rats. Japanese Journal of Complementary and Alternative Medicine 6 (2): 105-10. doi:10.1625/jcam.6.105.

11. Hore, D. K., and R. S. Rathi. 2007. Characterization of job's tears germplasm in NorthEast India. Indian Journal of Natural Products and Resources 6 (1): 50-54.

12. Hsia S, Yeh C, Kuo Y, Wang PS, and Chiang W. 2007. Effects of adlay (Coix lachrymajobi L. var. ma-yuen Stapf.) hull extracts on the secretion of progesterone and estradiol in vivo and in vitro. Experimental Biology and Medicine (Maywood, N.J.) 232 (9): 1181-94. doi:10.3181/0612-RM-306.

13. Jampeetong A, Konnerup D, Piwpuan N, and Brix H. 2013. Interactive effects of nitrogen form and $\mathrm{pH}$ on growth, morphology, $\mathrm{N}$ uptake and mineral contents of Coix lacryma-jobi L. Aquatic Botany 111. Elsevier B.V.: 144-49. doi:10.1016/j.aquabot.2013.06.002.

14. Juhaeti, Titi. 2015. Jali (Coix lacryma-jobi L.; Poaceae) for food diversification: its productivity under various doses of fertilization. Biologi 14 (2): 163-68. [Indonesian]

15. Kennedy G, Warren TK, Lee CT, Ruth C, and Ji Yen AT. 2017. Guildelines on Assessgin 
Biodiverse Foods in Dietary Intake Surveys. Rome: FAO United Nations.

16. Lakkham K, Wangsomnuk $P$, and Aromdee C. 2009. Identification and quality of four varieties of adlay. Songklanakarin Journal of Science and Technology 31 (4): 425-31.

17. Li WL, Zheng HC, Bukuru J, and De Kimpe N. 2004. Natural medicines used in the traditional Chinese medical system for therapy of diabetes mellitus. Journal of Ethnopharmacology 92 (1): 1-21. doi:10.1016/j.jep.2003.12.031.

18. Lugli J, Campbell A, Gaziola SA, Smith RJ, Lea PJ, and Azevedo RA. 2002. Enzymes of lysine metabolism from Coix lacryma-jobi seeds. Plant Physiology and Biochemistry 40 (1): 25-32. doi:10.1016/S0981-9428(01)01343-2.

19. Nurmala T. 2011. Potensi dan prospek pengembangan hanjeli (Coix lacryma-jobi L.) sebagai pangan bergizi kaya lemak untuk mendukung diversifikasi pangan menuju ketahanan pangan mandiri. Pangan 20 (1): 41-48. [Indonesian].

20. Protabase. 2009. Coix lacryma-jobi L. Plant Resources of Tropical Africa, 1-10.

21. 21. Qu D, He JJ, Liu CY, Zhou J, and Chen Y. 2013. Triterpene-loaded microemulsion using Coix lacryma-jobi seed extract as oil phase for enhanced antitumor efficacy: Preparation and in vivo evaluation. International Journal of Nanomedicine 9 (1): 109-18. doi:10.2147/IJN.S54796.

22. Ragasa, CY, Torres OB, Tongco JVV, and Razal RA. 2014. Chemical constituents of Coix lacryma-jobi. Research Journal of Pharmaceutical, Biological and Chemical Sciences 5 (181): 181-86.

23. Ruminta, Nurmala T, and Wicaksono FY. 2017. Growth and yield of Job's tears (Coix jacryma-jobi L.) response to different types of Oldeman climate classification and row spacing in West Java Indonesia." Journal of Agronomy 16 (2): 76-82. doi:10.3923/ja.2017.76.82.

24. Sage RF and Kubien DS. 2007. The temperature response of C3 and C4 photosynthesis. Plant, Cell and Environment, 1086-1106. doi:10.1111/j.1365-3040.2007.01682.x.

25. Shiva Ram Bhandari, SR, Park SK, Cho YC, and Lee YS. 2012. Evaluation of phytonutrients in adlay (Coix lacryma-jobi L.) seeds. African Journal of Biotechnology 11 (8): 1872-78. doi:10.5897/AJB11.2416.

26. Singha, K., Choudhary, R., and Vishnu, K. (2014). Growth and Diversification of Horticulture Crops in Karnataka: An Inter-District Analysis.

27. Van den Bergh MH and lamsupasit N, 1996. Coix lacryma-jobi L. [Internet] Record from Proseabase. Grubben GJH and Partohardjono S. (Editors). PROSEA (Plant Resources of South-East Asia) Foundation, Bogor, Indonesia. http://www.proseanet.org. Accessed from Internet: 17-Jul-2017.

28. Wahyuningsih, S. (2008). Diversifikasi Pertanian. MEDIAGRO, 4(1), 1-11.

29. Xi XJ, Zhu YG, Tong YP, Yang XL, Tang NN, Ma SM, Li S, and Cheng Z. 2016. Assessment of the genetic diversity of different Job's tears (Coix lacryma-jobi L.) accessions and the active composition and anticancer effect of its seed oil. PLoS ONE 11 (4): 1-22. doi:10.1371/journal.pone.0153269.

30. Yamori W, Hikosaka K and Way DA. 2014. Temperature response of photosynthesis in C3, C4, and CAM plants: temperature acclimation and temperature adaptation. Photosynthesis Research 119 (1-2): 101-17. doi: 10.1007/s11120-013-9874-6. 